updating of the system for training specialists in the pharmaceutical industry in Ukraine have been theoretically substantiated.

For all educational institutions in different countries that train pharmacists, with a wide variety of requirements for their professional activities, there is a common factor influencing the quality and accessibility of education - a certain choice of the form of training - traditional (full-time) and distance learning. Given this, it should be noted that the content of pharmaceutical education, descriptions, and structure are available for students on the corresponding web resources, i.e., for use at a distance. Students get the opportunity to study at a time convenient for them, regardless of their location. They can interrupt the educational process due to personal circumstances, and later return to it. The training course provides them with the opportunity to interact with and learn from highly qualified and experienced professionals.

The described foreign experience actualizes the tasks and directions of the reorganization of the traditional pharmacist training system in $U$ kraine. The main idea is to create a model of the education system, which will be aimed at providing everyone with the possibility of obtaining and replenishing knowledge, professional development, improvement and professional self-realization throughout life.

Keywords: pharmacist, education, preparation, educational institution, microbiology, virology, immunology, continuity, distance education.

DOI: https://doi.org/10.31392/NZ-npu-142.2019.13

УДК 821.161 .2

Коваленко О. А.

\title{
ЕКЗИСТЕНЦІЙНИЙ ЗМІСТ ОСНОВНИХ ІДЕЙ В ІНТИМНО-МЕДИТАТИВНІЙ ЛІРИЦІ Т. Г. ШЕВЧЕНКА
}

Аналізуються проблеми інтимно-медитативної лірики Т. Г. Шевченка, написаної у період після його повернення із заслання. Обгрунтовується принџиповий антропоцентризм, притаманний світосприйняттю Т. Г. Шевченка, який зумовлює осягнення навколишнього світу, природи України, історії і культури украӥнського народу крізь призму нерозривності людського буття $i$ світу, суб’єктивного $i$ об'єктивного, турбот, переживань, потреб $i$ прагнень особистості.

У статті наведено дослідження нових аспектів екзистенщійного змісту конфлікту в інтимно-медитативній поезії Т. Г. Шевченка, створеній в останні роки його життя.

Внутрішній душевний конфлікт людини (прагнення до свободи і відсутність ї̈) тут чітко простежується в кожному з рядків поезії, які виражають прагнення їі екзистениії вийти в безкінечне, позачасове, трансцендентне буття за допомогою медитаиії.

Аналіз інтимно-медитативної лірики Т. Г. Шевченка свідчить про наявність у ній иілого "розсипу" глибоких ідей, що носять екзистенційний характер $і$ мають велику сучасну філософську иінність.

Поет стверджує, щуо бездуховне суспільство сприяє падінню моральних изінностей $i$ створюе умови, за яких гостро постають проблеми існування людини, ї занедбаності, сприйняття світу як чужого, ворожого для неї; затверджує необхідність утвердження в суспільстві доленосних людських иінностей (добра, обов'язку, справедливості, краси, віри, та ін.); констатує необхідність утвердження в суспільстві свободи, як одного з основних визначень людського буття. Свобода для Т. Г. Шевченка - ие мета існування людини; переконання в тому, що людина може стати щасливою лише за умови, що ї̈ народ також щасливий. 
Реалізується наскрізна теза дослідження - для Кобзаря весь світ уособлює Україна. Для нього Україна - екзистениійний стан свого індивідуального буття.

Ключові слова: екзистенщія, свобода, дійсне і недійсне існування, турбота, внутрішній монолог, пошук иляхів вибору самореалізаџії в суспільстві.

Т.Г.Шевченко, як і його сучасник С. К'єркегор, стояв у витоків екзистенціалізму. Не будучи професійним філософом, однак ставши всебічно обізнаною і спостережливою людиною, поет розгледів недолік сучасної йому фрілософії, суть якого полягала в надмірному акцентуванні уваги фрілософрів і митців на з'ясуванні суті людини, і незаслуженому відсуванні на другий план вивчення проблем її існування. Тому своє завдання мислитель вбачав у поверненні до людини, осягненні ії інтересів. Необхідно допомогти людині знайти свою правду, невпинно стверджував Кобзар, тобто таку істину, заради якої їй хотілося б жити і померти. Як це зробити, поет демонстрував у своїй інтимній медитативній ліриці. Він був занепокоєний тим, що на фоні "в'ялого" гуманізму в суспільних відносинах, у поезії переважає консерватизм, бюрократизм і пересічність.

Феномен екзистенції цікавив багатьох дослідників, починаючи із засновників сучасного екзистенціалізму М. Гайдеггера, А. Камю, Г. Марселя, Ж.-П. Сартра, К. Ясперса та ін. Не втрачається інтерес до нього і в наші дні. Окремі проблеми цього ірраціонального напряму широко представлені у дослідженнях С. С. Авєрінцева, П.П.Гайденко, Р. Р. Москвіної, А. М. Руткевича, Т. М. Тузової та ін. Не згасає інтерес і до екзистенційного спадку Т.Г.Шевченка, тому що його творчість невичерпна, а фрілософія Кобзаря завжди актуальна. Ідеї мислителя про скінченність, смертність людини, тимчасовість, обмеженість і конфліктність її існування, прагнення до свободи і родинного щастя та інші знайшли своє відображення у творчості вітчизняних фрілософрів і фрілологів О.П. Мовчанюка, Т.С. Мейзерської, В. О. Шевчука та ін. Прийдешні покоління українців також знаходитимуть у поетичному спадку Кобзаря, у тому числі і в інтимній медитативній ліриці поета, нові екзистенційні ідеї, варті ретельного дослідження.

Mema cmammi - дослідження нових аспектів екзистенційного змісту конфлікту в інтимно-медитативній поезії Т.Г. Шевченка, створеній в останні роки його життя.

Велику фрілософську і художню цінність для обраної теми досліджень становить лірика Т.Г.Шевченка, представлена значною кількістю поезій, передусім такими творами, як: “Росли у купочці, зросли...", “Ликері", “Л." ("Поставлю хату і кімнату..."), "Н. Т.", "Кума моя і я...", "Якби з ким сісти хліба з"їсти...", "Чи не покинуть нам, небого..."та ін.

Лірика останнього періоду творчості поета певною мірою продовжує традицію його рефлексивної поезії 1847-1850-х років. Однак є в ній і певні відмінності. Так, на думку шевченкознавця В. Мовчанюка, "характерна риса цієї лірики - щирість душевної сповіді, внутрішнього монологу - розмови з самим собою. Ця сповідь перед власним “Я" - осмислення своєї життєвої інтуїції ведеться в тональності, що не допускає будь-якої романтичної гіперболізації чи романтичної прози [4, с. 128].

Подібні переживання Т.Г. Шевченка спостерігаються і в інших творах цього періоду. Наприклад, у поезії "Над Дніпровою сагою" ми бачимо 
зажуреного поета, який вніс до свого ліричного твору яскраво виражений автобіографрічний стан душі. Ця поезія нагадує переспів народної пісні 3 власними екзистенційними корективами та варіаціями:

Стоїть старий, похилився,

Мов козак той зажурився.

Що без долі, без родини

Та без вірної дружини... [8, с. 348].

Душевний стан поета пронизують смуток, почуття самотності і журби. Він одинокий, знесилений, але духовно не зломлений, тому намагається всебічно охопити єдиним поглядом усе своє життя, свою творчість, заглибитися у сенс існування свого “Я" і зробити свій правильний життєвий вибір. Ці ж почуття своєрідно відбилися і в написаній наступного дня поезії "Росли у купочці, зросли". Поезія нагадує собою романтичну ідилію двох закоханих людей.

На нашу думку, в цьому творі відбилися мрії поета про щасливе особисте повноцінне життя, причому вільних від кріпацтва людей, для яких свобода одна з основних цінностей людини.

Внутрішній душевний конфлікт людини (прагнення до свободи і відсутність іiі) тут чітко простежується в кожному з рядків поезії, які виражають прагнення її екзистенції вийти в безкінечне, позачасове, трансцендентне буття за допомогою медитації (пізніше цей аспект екзистенціалізму був творчо опрацьований К. Ясперсом, Г. Марселєм та їхніми учнями).

Розгортаючи цю думку, дослідник творчості Т.Г. Шевченка В. Шевчук у своїй статті стверджує: “В останньому періоді творчості Т. Шевченко не тільки не полишає теми родини, але поглиблює їі й розширює, побіч із давніми освоєними мотивами, творячи нові" [8, 9, с. 191].

Акцентуємо увагу на такому аспекті душевного стану поета: яке палке у нього бажання одружитися, "отак цвісти" у своїх почуттях до коханої жінки! Ці рядки народилися в Петербурзі, а через десять днів у Стрельні з-під пера Кобзаря виходить поезія “Ликері. На пам'ять. 5 серпня 1860 року”. Пригадаймо, що інтимні поезії присвячував поет й іншим жінкам, що стрічалися на його життєвому шляху, але Ликера, за словами П. Федченка, це сумовита медитація за передчасно помороженим та потоптаним барвінком і трагічний зойк відчайної людини" [6, с. 279].

Ликера Полусмакова була кріпачкою Шевченкового знайомого М. Я. Макарова. Довгий час поета і дівчину вважали нареченими, але між ними стався розрив, ініціатором якого, на думку О.Дорошкевича, “був поет, а причиною - легковажна поведінка нареченої" [1, с. 83].

Відомо також, що мало хто із знайомих Кобзаря схвалював ці стосунки, але поет доводив, що його почуття щирі, надзвичайно глибокі і сильні:

Моя ти любо! Усміхнись,

І вольную святую душу

І руку вольную, мій друже,

Подай мені. [8, с. 351].

Розрив з двадцятирічною дівчиною боляче травмував поета, бо його згорьована душа шукала любові і сім'ї, того родинного раю, про який мріє будьяка людина. Але, на жаль, вже немолодій сорокашестирічній людині довелося знову залишитись на самоті. У поезії “Л." (“Поставлю хату і кімнату...") поет 
знову говорить про свої почуття, але дуже стримано і схвильовано, нібито прагнучи все це забути, як страшний сон, “бо у своїй нареченій знайшов мало тієї поезії, яку малювала йому уява, і наштовхнувся на прозаїчну дійсність, що видалася йому пошлістю" [6, с. 157].

Перші рядочки вірша звучать ідилічно, бо ие мрї:

Поставлю хату і кімнату,

Садок-райочок насажу... [8, с. 354].

Але як тільки поет повертається до реальності, ми відразу помічаємо загострення його екзистенційних пошуків, що страшить мислителя неспокоєм і зрадою почуттів:

Підкрадешся, наробии лиха...

Запалиш рай мій самотний. [8, с. 354].

Подібне розуміння і відчуття втрати нареченої ми бачимо і в поезії "Н. Я. Макарову" ("Барвінок цвів і зеленів"), написаному в Петербурзі. Чому саме цій людині присвячено вірш? Відповідь проста - Н. Я. Макаров порадив Т.Г. Шевченкові не поспішати, а добре подумати про взаємини з Ликерою в подальшому:

Барвінок извів і зеленів,

Слався, розстилався;

Та недосвіт передсвітом

В садочок укрався. [8, с. 353].

Подібна образність вірша може сприйматися також і в іншій, більш загальній площині: барвінок - це не тільки символ весілля, одруження 3 Ликерою, якого так бажав Т. Г. Шевченко, але й образ його сподівань, так само як і недосвіт - не тільки плітки з приводу його сватання до Ликери, люди, які прагнули перешкодити його весіллю, загалом обставини, що роз'єднали наречених, але й власні сумніви поета перед важливим життєвим кроком. Сила внутрішнього конфлікту підкреслює тут напругу переживань поета, тому в останніх рядках він шкодує за "недосвітом" (молодою нареченою), що так потоптала його надії. У своїй праці “Тарасові музи” дослідник творчості поета Ю. Ковтун зазначила: "Вічною стала творчість Кобзаря, вічними стали його музи, які мали щастя зустрітися з ним, надихнути його поетову душу" [2, с. 192].

Упродовж жовтня-листопада 1860 року з'являються й інші поезії Т.Г.Шевченка, але всі вони поєднані трагізмом долі, заглибленістю в його особисті переживання. Холодом віє від поезії “Минули літа молодії....":

Минули літа молодї,

Холодним вітром од надії

Уже повіяло. Зима!... [8, с. 359].

Останнє слово "зима" перегукується зі словами "нема, анікогісінько нема" напружено і розривно, нібито автор прослуховується до їх відгомону у власному серці. Ця виразність відчутна завдяки знову-таки екзистенційним виявам:

Не жди весни - святої долі!

Вона не зійде вже ніколи... [8, с. 359].

Бо не прийшла весна із зеленим садочком до поета наступного 1861 року. Гіркою самотою віє від думки, настільки одиноким був поет, настільки вже безнадійним... Його вірш “Якби з ким сісти хліба з"їсти” цьому повне 
підтвердження. Але й цього разу дочка Р. Витавського, яку пропонували в наречену поету, була вже зарученою. Знову крах планів і надії поета. Повна самотність не давала спокійно жити, творити щось інше.

Чому поет не отримав кращої долі, сімейного щастя, все життя засіваючи добром землю? Чому не зустрів своєї половини? Причиною, на наш погляд, $є$ не тільки сукупність об'єктивних обставин, що склалися під час його життя, але й роздвоєність між почуттями розуму і серця поета, особливо, в останній період його життя.

Ще одним твором, тісно пов'язаним із подіями розриву з Ликерою Полусмаковою восени 1860 року, вважаємо вірш “Зійшлись, побрались, поєднались...". Спочатку поезія надзвичайно ідилічна: “поєднались", “садочок розвели", “дітей виростили"... Якщо перша частина вірша наповнена певним внутрішнім спокоєм, то друга його частина руйнує гармонію людського щастя, щастя простої людини. Сила внутрішніх переживань виражає тут заперечення ідилії, спростування думок про щасливе майбутнє пересічної людини у ворожому для неї світі:

А неначе розійшлись,

Неначе брались - не єднались. [8, с. 370].

У цих рядках розкривається провідна ідея вірша: поет наче зливає в ціле свою самотність з величезним народним горем і розуміє, що його мрія про особисте щасливе сімейне життя - нездійсненна.

Інтимна лірика останнього періоду якоюсь мірою продовжує окремі теми попередніх подій у житті поета, але в ній ще більше присутні настрої смутку. Свою ненависть до святенницької моралі і войовниче ствердження права жінки на особисте життя вклав поет у дві поезії "Н. Т." та “Кума моя і я". У віршах згадується Тарновська Надія, сестра чернігівського поміщика-мецената В. В. Тарновського.

Відомо, що в 1845 році Т. Г. Шевченко разом із Надією хрестив дитину у місцевого диякона; познайомився з ії особистим життям і тому називає ії "великомученице кума" [8, с. 369]. Своєрідно підійшов поет до висвітлення долі своєї куми, написавши:

Рожевим ивітом проивіла

І раю красного не зріла... [8, с. 369].

Він іронізує упродовж усього твору якось по-доброму, натякаючи на суворі догми християнської моралі. Тут відчувається негативне ставлення мислителя до всього консервативного у стосунках, в усіх фоормах комунікації індивідів. Ця проблема також згодом посяде центральне місце у засновників сучасного екзистенціалізму Ж.-П. Сартра і А. Камю, які такі норми моралі назвуть "фральшем" і “святенництвом". Особливо негативне ставлення засвідчує поет до норм усталеної поведінки жінки в тодішньому суспільстві:

Прокинься, кумо, пробудись

Та кругом себе подивись... [8, с. 369].

За одинадцять днів до смерті хворий Кобзар написав 36 рядків свого останнього твору “Чи не покинуть нам, небого...". Трансформована гама інтимних почуттів відлунюється і в цьому творі Кобзаря: на землі не судилося йому мати щастя, родинного зокрема. Шевченкознавець Є. Ненадкевич говорить про вірш “Чи не покинуть нам, небого...” як про ліричну медитацію, 
породжену фрілософським усвідомленням неминучості: “По суті, це епілог у ширшому розумінні - прощання з світом, з життям, прощальна сповідь поетафілософа. У цих роздумах розкривається велич духу мужньої людини, в них відсутні малодушні скарги на долю, розгубленість, розлука, страх перед невідомим..." [5, с. 85-86].

Майже в усіх останніх віршах, наповнених внутрішнім конфліктом, Кобзар передає силу почуттів творця, його важкі думи, надії та мрії. Цей твір, як не один, конкретно спрямовує всі роздуми поета в останню путь і має конкретного співбесідника:

Чи не покинуть нам, небого,

Моя сусідонько убога,

Вірші нікчемні віршувати,

Та заходиться риштувать

Вози в далекую дорогу... [8, с. 372].

Цілком очевидно, що тут звертається поет до музи, з якою пліч-о-пліч пройшли життя разом, творили "нікчемні" вірші. Тема смерті не вперше з'являється в творчості Т. Г. Шевченка. У зв'язку з цим Ю. Шевельов пише: 'Ще ніхто не проаналізував прямі й непрямі розгалуження цієї теми в поетовій творчості, зміни в його ставленні до смерті" [7, с. 99].

Це дійсно так. Збираючись в останню путь, Тарас Григорович дивиться на "сей світ", на його велич, хоч нічого теплого так і не бачив у ньому. Болем звучать слова цієї поезії, внутрішній різновид конфлікту обплутав кожне слово його твору. Наявність дати під 36-м рядком незаперечно доводить, що, записавши їі, поет вважав вірш закінченим. Так прощався мислитель зі світом:

Благослови мене, друже,

Славою святою... [8, с. 373].

Але Бог дав поетові ще добу творчості. I тому друга частина вірша починається згадкою про Ескулапа, Харона, Парку-пряху... Всі ці образи пов'язані з перенесенням на "той" світ, з роздумами про славу "святую" про той слід, що залишила у цьому світі людина, про її відповідальність за свої життєві вчинки, насамперед перед Україною, славними предками... Яка сила духу рухала думки Кобзаря, і яке величезне бажання жити у вільній Україні чуємо в рядках, що стали “лебединою піснею":

Неначе над Дніпром широким,

В гаю - предвічному гаю,

Поставлю хаточку, садочок... [8, с. 373].

"Символічно, що саме так обірвалися останні поетичні рядки Т. Г. Шевченка. Рефлексивне коло роздумів автора нібито замкнулося з тим самим Дніпром та українськими гаями і горами, що у заспіві “Причинної", але вже в іншому контексті" [6, с. 281].

Аналізуючи останні поетичні "сповіді" Т.Г. Шевченка, погоджуємося 3 думкою Т. Мейзерської про відображення у творчості Кобзаря екзистенційного конфлікту, який дійсно "позначається як внутрішнє співвідношення індивіда 3 самим собою, що експлікує переживання не зовнішнього світу, а фрагментів свого суб'єктивного буття..." [3, с. 53]. Однак добавимо, що цей внутрішній стан (екзистенція) нерозривно пов'язаний із зовнішнім буттям .

Висновки. Отже, далеко не повний аналіз інтимно-медитативної лірики 
Т.Г. Шевченка, написаної в роки після його повернення із заслання, свідчить про наявність у ній цілого "розсипу" глибоких ідей, що носять екзистенційний характер і мають велику сучасну фрілософську цінність. До них, на наш погляд, відносяться наступні: по-перше, необхідність перебудови тогочасного українського суспільства на справедливих, гуманістичних засадах. Поет стверджує, що бездуховне суспільство сприяє падінню моральних цінностей і створює умови, за яких гостро постають проблеми існування людини, її занедбаності, сприйняття світу як чужого, ворожого для неї; по-друге, необхідність утвердження в суспільстві доленосних людських цінностей (добра, обов'язку, справедливості, краси, віри, та ін..); по-третє, подолання людиною страху перед смертю, яка $€$ найбільшим злом для неї, завдяки медитації, створенню добрих справ, пам'ять про які буде вічною; по-четверте, констатація необхідності утвердження в суспільстві свободи, як одного 3 основних визначень людського буття. Свобода для Т.Г. Шевченка - це мета існування людини; по-п'яте, переконання в тому, що людина може стати щасливою лише за умови, що ії народ також щасливий. Всі ці та інші ідеї вітчизняного мислителя тією чи іншою мірою знайшли відображення в різних течіях сучасного екзистенціалізму, який зародився на початку XX століття.

\section{Використана література:}

1. Дорошкевич О. К. Трагедія самотнього життя. Життя й революиія. № 9. 1926. С. 83.

2. Ковтун Ю. І. Тарасові музи. Київ : Україна, 2003. 206 с.

3. Мейзерська Т. С. Слово Шевченка: міф, метафора, історія. Наукове есе. Одеса : Астропринт, 1996. $61 \mathrm{c.}$

4. Мовчанюк В. П. Медитативна лірика Т. Г. Шевченка. Київ : Наук. думка, 1993. 146 с.

5. Ненадкевич Є. О. Творчість Т. Г. Шевченка після заслання 1857-1858 рр. Київ : Держхудліт, 1956. $105 \mathrm{c.}$

6. Федченко П. М. Т. Г. Шевченко. Київ : Наук. думка, 1989. 236 с.

7. Шевельов Ю. В. 1860 рік у творчості Т. Шевченка. Записки наукового товариства ім. Т. Шевченка. Праиі філологічної секиії. Т. 224. Львів: ЛДУ. С. 101-109.

8. Шевченко Т. Г. Зібрання творів : у 6 т. Т. 2: Поезія 1847-1861 / редкол. : М. Г. Жулинський (голова) та ін. Київ : Наук.думка, 2001. 784 с.

9. Шевчук В. О. Універсальна картина світу у творчості письменників українського бароко. Україна. Наука і культура. Вип. 28. 1994. С. 192-201.

\section{References:}

[1] Doroshkevych O. K. (1926). Trahediia samotnoho zhyttia. Zhyttia y revoliutsiia. № 9. S. 83.

[2] K ovtun Y u. I. (2003). Tarasovi muzy. K yiv : U kraina, $206 \mathrm{s.}$

[3] M eizerska T. S. (1996). Slovo Shevchenka: mif, metafora, istoriia. Naukove ese. Odesa : A stroprynt, $61 \mathrm{s.}$

[4] M ovchaniuk V. P. (1993). M edytatyvna liryka T. H. Shevchenka. K yiv : Nauk. dumka, $146 \mathrm{~s}$.

[5] Nenadkevych Y e. O. (1956). TvorchistT. H. Shevchenka pislia zaslannia 1857-1858 rr. Kyiv: Derzhkhudlit, $105 \mathrm{~s}$.

[6] Fedchenko P. M . (1989). T. H. Shevchenko. K yiv : Nauk. dumka, $236 \mathrm{~s}$.

[7] Shevelov Y u. V. 1860 rik u tvorchosti T. Shevchenka. Zapysky naukovoho tovarystva im. T. Shevchenka. Pratsi filolohichnoi sektsii. T. 224. L viv : LDU. S. 101-109.

[8] Shevchenko T. H. (2001). Zibrannia tvoriv : u 6 t. T. 2 : Poeziia 1847-1861 / redkol. : M. H. Zhulynskyi (holova) ta in. K yiv : Nauk.dumka, $784 \mathrm{~s}$.

[9] Shevchuk V. O. (1994). Universalna kartyna svitu u tvorchosti pysmennykiv ukrainskoho baroko. U kraina. Nauka i kultura. Vyp. 28. S. 192-201. 


\section{КовАЛЕНкоО.А. Экзистенционное содержание основных идей в интимно- медитативной лирике Т. Г. Шевченко.}

Анализируются проблемы интимно-медитативной лирики Т. Г. Шевченка, написанной в период после его возвращения из ссылки. Обосновывается принципиальный антропоцентризм, присущий мировосприятию Т.Г.Шевченка, который предопределяет постигание окружсающего мира, природы Украины, истории и культуры украинского народа сквозь призму неразрывности человеческого бытия и мира, субъективного и объективного, забот, пережсиваний, потребностей и стремлений личности.

В статье приведены исследования новых аспектов экзистенциильного содержания конфликта в интимно-медитативной поэзии Т. Г. Шевченко, созданной в последние годы его жизни. Внутренний душевный конфликт человека (стремление к свободе и ее отсутствие) здесь четко прослежсивается в каждой из строчек поэзии, которые выражают стремление ее экзистенции выйти в бесконечное, вневременное, трансиендентное бытие с помощью медитации. Анализ интимно-медитативной лирики Т. Г. Шевченко свидетельствует о наличии в ней целой "россыпи" глубоких идей, носящих экзистенщиальный характер и имеющих большую современную философскую иенность.

Поэт утверждает, что бездуховное общество способствует падению моральньх иенностей и создает условия, при которых остро встают проблемы существования человека, его заброшенности, восприятие мира как чужого, враждебного для нее; утверждает необходимость установления в обществе судьбоносных человеческих иенностей (добра, долга, справедливости, красоть, веры, и др.); констатирует необходимость утверждения в обществе свободы, как одного из основных определений человеческого бытия. Свобода для Т. Г. Шевченко - это иель существования человека; убеждение в том, что человек может стать счастливым лишь при условии, что ее народ тоже счастлив.

Реализуется сквозной тезис исследования - для Кобзаря весь мир олицетворяет Украина. Для него Украина - экзистенционное состояние своего индивидуального бытия.

Ключевые слова: экзистенция, свобода, действительное и недействительное существование, беспокойство, внутренний монолог, поиск путей выбора самореализачии в обществе.

Kovalenko E. A. The existential content of the main ideas in the intimate and meditative Iyrics of T. G. Shevchenko.

The problems of the intimate and meditative lyrics by T.G. Shevchenko, written in the period after his return from exile, are analyzed. The influence on the poet's specific social position created by the poet is emphasized. It is argued that it was this circumstance that caused the thinker to choose the role of a mediator, a poet-prophet, who, on the one hand, was not a peasant, but assumed the function of a representative of the spiritual values of his people, whose carrier in those times was primarily the peasantry.

The main purpose is to show, on the one hand, the socio-philosophical and socio-political themes of poetry written by T.G. Shevchenko after the exile, on the other hand it is emphasized the importance of the intimate and meditative lyrics, written by the author in that period. As a result we can see a new type of poetry, where the thinker appeals to representatives of the highest circles of U krainian society to be carriers of real philosophy, the core of which is the problem of the meaning of human existence.

Results. It is demonstrated that such a civic stand of a poet is possible only thanks to the complete identification of himself with U kraine. The principal anthropocentrism inherent in T. G. Shevchenko's worldview is substantiated, which conditions the understanding of the surrounding world, the nature of U kraine, the history and culture of the U krainian people through the prism of the continuity of human existence and the world, the subjective and objective, concerns, experiences, needs and aspirations of the individual.

Originality. A through-thesis research is being implemented - for Kobzar, the whole world is personified by U kraine. For him, Ukraine is the existential state of its individual being.

Conclusion. The personal fate of the poet, the collapse of so desired dreams of creating your own 
family become a reflection of each other. That is why the image of Ukraine, how it emerges in the poet's intimate lyrics, the demonstration of the moral model of the attitude towards a woman, family and personality as a whole, formed on the emotional, sensual level the ground that led in the times of life of T.G. Shevchenko and the further history of Ukraine, to the focus of intellectual searches, the efforts of researchers of the K obzar heritage in order to develop the philosophy of the $U$ krainian idea.

Keywords: existence, freedom, present and unreal existence, care, internal and external conflict, the search for ways to choose self-realization in society.

DOI: https://doi.org/10.31392/NZ-npu-142.2019.14

УДК 7.071.2:784

Ладний А. С., Кедіс О. Ю.

\section{КОМУНІКАТИВНІ АСПЕКТИ ДІЯЛЬНОСТІ ХОРОВОГО ДИРИГЕНТА}

У статті аналізуються ті завдання, щзо постають перед хоровим диригентом. Визначено комунікативний характер даного типу виконавської діяльності. Музичний твір розгортається у часі та наповнюється сенсом, якщо він отримує вірного прочитання з боку виконавців та передається слухачам. Підкреслено багатовекторність комунікації, яка здійснюється диригентом у ході знайомства з музичним твором, його аналізом, розробкою, виконанням. Зазначено, щуо при виконанні обробок народних пісень відбувається створення додаткових сенсів, що потребують свого розшифрування. Наголомено на визначній ролі жесту та міміки як універсальних засобів спілкування між диригентом та виконавським колективом. Завдяки налаштованості виконавців-хористів до співдії буде досягатися комунікація, коли найменша зміна нюансування буде передаватися від диригента до виконавців. Сднання диригента та виконавського колективу в емоційно-творчому пориві є запорукою плідної співдї, результатом якої стає донесення твору до слухача.

У статті висвітлено особливості комунікаиії, яку здійснює хоровий диригент при роботі над музичним твором, його виконанні та взаємодії з учасниками творчого прочесу.

Диригент є виконавцем, чия діяльність за своєю сутністю має комунікативний характер. Специфіка його комунікаиї пов'язана з роботою над музичним твором, який виступає своєрідним смислоутворюючим містком до композитора. У разі виконання обробки народної пісні перед диригентом постає більш складне завдання, адже додається завдання розшифрування тих кодів, що закладені у фольклорному першоджерелі. Неодмінною частиною комунікативного процесу, який здійснює диригент, є робота з колективом виконавиів, яка впроваджується завдяки таким засобам, як жест та міміка. Подальша експлікація комунікативної теорії по відноченню до різних сфер виконавської музичної діяльності уявляється перспективним напрямком.

Ключові слова: хоровий диригент, виконавець, комунікачія, творчість, обробка.

Діяльність хорового диригента включає чимало завдань. Це і знання музичного матеріалу, вміння опрацьовувати нові твори, робота з виконавцями, навички аранжування народнопісенного матеріалу - це не повний перелік того, що має вміти хормейстер. Разом з тим, провідне значення має здатність бути частиною комунікативного процесу, який розгортається між усіма учасниками 